\title{
Controlled deterioration test to evaluate the physiological potential of sweet corn seeds
}

\section{Teste de deterioração controlada para avaliação do potencial fisiológico de sementes de milho doce}

\author{
Jéssica de Lucena Marinho ${ }^{1 *}$; José Henrique Bizzarri Bazzo²; Claudemir Zucareli2; \\ Inês Cristina de Batista Fonseca²
}

\section{Highlights}

The controlled deterioration test satisfactorily estimated seed vigor.

The shortest deterioration period was more efficient for sweet corn.

The shortest exposure and evaluation period of test is more efficient and indicated.

\begin{abstract}
The evaluation of the physiological potential of sweet corn seeds is essential in a quality control program and the choice of vigor tests using an adequate analysis methodology is essential to obtain reliable results. In this sense, this study aimed to standardize the methodology of the controlled deterioration test through combinations between time and temperature to evaluate the vigor of sweet corn seeds. Six lots of sweet corn seeds were characterized by the degree of moisture and the initial physiological potential through the following tests: germination, first germination count, cold test, electrical conductivity, accelerated aging, length and dry mass of normal seedlings, seedling emergence in sand, and emergence rate index. Subsequently, these lots had their initial water content adjusted to $20 \%$ using the wet substrate method. The seeds from the six lots were subjected to the controlled deterioration test under two temperatures for four periods, obtaining a completely randomized design in an $8 \times 6$ factorial scheme with eight combinations of time/temperature and six lots. Germination and the first germination count were evaluated after the deterioration test. The data were subjected to analysis of variance with a comparison of means by the Tukey test at a $5 \%$ significance. The results of the first count and germination tests after deterioration were subjected to a simple linear correlation study together with the initial characterization data. The combinations $8 \mathrm{~h}-40^{\circ} \mathrm{C}$ and $8 \mathrm{~h}-45^{\circ} \mathrm{C}$ in the controlled deterioration test were efficient in distinguishing the vigor of seed lots. The shorter exposure period and the first germination count after deterioration are more suitable for evaluating the vigor of sweet corn seeds.
\end{abstract}

Key words: Artificial aging. Germination. Vigor. Zea mays convar. saccharata. Special corn.

Doctoral Student in Agronomy, State University of Londrina, UEL, Londrina, PR, Brazil. E-mail: jlmarinho@live.com

2 Profs. Drs., Department of Agronomy, UEL, Londrina, PR, Brazil. E-mail: josebazzo@uel.br; claudemircca@uel.br; inescbf@uel.br

* Author for correspondence

Received: May 19, 2020 - Approved: Nov. 11, 2020 


\section{Resumo}

A avaliação do potencial fisiológico de sementes de milho doce é essencial em um programa de controle de qualidade e, a escolha de testes de vigor com uma metodologia de análise adequada é fundamental para a obtenção de resultados confiáveis. Neste sentido, objetivou-se padronizar a metodologia do teste de deterioração controlada, por meio de combinações de tempo e temperatura, para avaliação do vigor de sementes de milho doce. Foram utilizados seis lotes de sementes de milho doce, caracterizados quanto o grau de umidade e o potencial fisiológico inicial por meio dos seguintes testes: germinação, primeira contagem da germinação, teste de frio, condutividade elétrica, envelhecimento acelerado, comprimento e massa seca de plântulas normais, emergência de plântulas em areia e índice de velocidade de emergência. Posteriormente, esses lotes tiveram o teor de água inicial ajustado para $20 \%$, pelo método do substrato úmido. Em seguida, sementes dos seis lotes foram submetidas ao teste de deterioração controlada sob duas temperaturas, por quatro períodos, obtendo-se um delineamento inteiramente casualizado em esquema fatorial $8 \times 6$, sendo 8 combinações de tempo/temperatura e 6 lotes. Após o teste de deterioração, foram avaliadas a germinação e a primeira contagem da germinação. Os dados obtidos foram submetidos à análise de variância com comparação de médias pelo teste de Tukey a 5\% de significância e, por fim, os resultados dos testes de primeira contagem e germinação após a deterioração, foram submetidos a estudo de correlação linear simples, juntamente com os dados da caracterização inicial. As combinações $8 \mathrm{~h}-40^{\circ} \mathrm{C}$ e $8 \mathrm{~h}-45^{\circ} \mathrm{C}$, no teste de deterioração controlada, foram eficientes na distinção do vigor dos lotes de sementes. O menor período de exposição e a primeira contagem da germinação, após a deterioração, são mais indicados para a avaliação do vigor de sementes de milho doce.

Palavras-chave: Envelhecimento artificial. Germinação. Vigor. Zea mays convar. Saccharata. Milhos especiais.

\section{Introduction}

Specific characteristics of sweet corn seeds, such as the highest sugar content and the smallest pericarp thickness, make them more susceptible to mechanical damage, entry and proliferation of pathogens, attack of pests, and deterioration, hindering the production of quality seeds (Kwiatkowski \& Clemente, 2007). Thus, the evaluation of the physiological potential of sweet corn seeds is essential in a quality control program because germination and vigor can estimate their potential for storage, commercialization, and use.

In this context, the choice of vigor tests with a simple, standardized and reproducible methodology is essential to obtain reliable results (Barbieri, Menezes, Conceição, \& Tunes, 2012), as the application of these evaluations for different species is routine in laboratories of research or seed analysis and should allow the results obtained to be compared and reproduced (Bento, Santos, Melo, \& Torres, 2010).

High humidity and temperature conditions trigger the seed deterioration process, affecting their vigor (Marcos, 2015). Thus, the controlled deterioration test, based on the behavior of germination after artificial aging, is promising in the discrimination of seeds with different vigor levels and deserves special attention from seed physiologists and technologists due to its simplicity, efficiency, and high correlation with the emergence of 
seedlings in the field (Dutra \& Medeiros, 2008; Marcos, 2015).

Controlled deterioration is a vigor test similar to that of accelerated aging, but with more precise control of temperature and humidity during the artificial aging period, which results in higher rigor, precision, and efficiency in distinguishing the physiological potential of seed lots (Santos, Trani, Medina, \& Parisi, 2011).

Deterioration occurs due to the exposure of seeds to high humidity and temperature for a certain period, and the study and identification of the best combination between these factors are important for the standardization of the test methodology (Zucareli, Cavariani, Sbrussi, \& Nakagawa, 2011).

Several authors have reported the use of controlled deterioration test to evaluate the vigor of seeds of different species (Silva \& Vieira, 2010; Torres, Dantas, Pereira, Benedito, \& Silva, 2012; Torres, Gomes, Silva, Benedito, \& Pereira, 2013; Morais \& Rossetto, 2013) including common corn (Zucareli et al., 2011), with the methodology (time and temperature) being specific to each crop, but with the initial water content of the seeds always around $20 \%$. However, no studies were found in the literature regarding the use of this test to evaluate the vigor of sweet corn seeds. Some characteristics of sweet corn, such as high sensitivity to soaking damage, the fragility of membranes, and the very thin pericarp, make it impossible for the use of the methodologies described for common corn seeds to be extrapolated to sweet corn seeds.

In this sense, this study aimed to standardize the methodology of the controlled deterioration test using combinations between time and temperature to evaluate the vigor of sweet corn seeds with initial water content adjusted to $20 \%$.

\section{Material and Methods}

Six lots of hybrid sweet corn seeds of Seminis Performance SeriesTM Single Pro SCTM (SV9298SN ${ }^{\circledR}$ ), carrier of the shrunken gene (sh2), which gives the seeds a super sweet character, were used in this study. The lots were characterized according to their initial physiological potential, using the following tests:

Degree of moisture: four replications, with whole seeds, were submitted to the oven method at $105{ }^{\circ} \mathrm{C}$ for 24 hours (Ministério da Agricultura, Pecuária e Abastecimento [MAPA], 2009).

Germination: eight replications of 50 seeds were placed on germination paper moistened at a proportion of 2.5 times its mass and maintained at $25{ }^{\circ} \mathrm{C}$, with normal seedling count carried out at 4 (first count) and 7 days (final count) after the test was set up (MAPA, 2009). The results were expressed as a percentage.

Cold test: conducted using the paper roll method with no soil, with four replications of 50 seeds sown on germination paper moistened at a proportion of 2.5 times its mass and maintained at $10 \pm 1^{\circ} \mathrm{C}$ for seven days and $25^{\circ} \mathrm{C}$ for another four days to count normal seedlings (Cícero \& Vieira, 1994). The results were expressed as a percentage.

Electrical conductivity: four replications of 50 seeds with the mass previously determined were soaked in $25 \mathrm{~mL}$ of distilled water for 24 hours at $25^{\circ} \mathrm{C}$ (Parera, Cantlife, 
Stofella, \& Scully, 1995). The results were expressed in $\mu \mathrm{S} \mathrm{cm}^{-1} \mathrm{~g}^{-1}$ of seeds.

Accelerated aging: four replications of 115 seeds were aged at $42{ }^{\circ} \mathrm{C}$ for 72 hours. Subsequently, the seeds were submitted to the germination test (Association of Official Seed Analysts [AOSA], 2009). The results were expressed as a percentage.

Seedling length: four replications of 10 seeds were sown on the upper third of a germination paper moistened with distilled water at a proportion of 2.5 times its mass. Rolls were made and remained in a germinator for four days at $25^{\circ} \mathrm{C}$ in the dark. After this period, the length of normal seedlings was measured (Nakagawa, 1999). The results were expressed in centimeters per seedling.

Seedling dry mass: the normal seedlings obtained in the length test were packed in paper bags and taken to a forced-air circulation oven at $80{ }^{\circ} \mathrm{C}$ until constant mass (Nakagawa, 1999), verified by successive weighings. The dry mass was evaluated and the results were expressed in $\mathrm{mg}$ per seedling.

Seedling emergence in sand: four replications of 50 seeds were sown in sandboxes. After 15 days, the number of seedlings with normal shoot development was counted. The results were expressed as a percentage.

Emergence rate index: performed together with the seedling emergence test in sand. Emerged seedlings were counted daily, which allowed calculating the emergence rate index (Maguire, 1962).

After the initial characterization, the sweet corn seeds of the six lots had the initial water content adjusted to $20 \%$ by the wet substrate method. For this, the seeds were wrapped in three germitest $^{\circledast}$ paper sheets moistened with water corresponding to 2.5 times its mass. Subsequently, rolls were made and remained in a BOD chamber at $25^{\circ} \mathrm{C}$ until reaching the previously determined mass (Marinho, Fonseca, \& Zucareli, 2020).

The seed mass was monitored periodically until reaching the pre-determined water content value. The seeds were then packed in properly sealed plastic bottles and remained at $10{ }^{\circ} \mathrm{C}$ for five days to standardize the water content.

After this standardization, about 160 $\mathrm{g}$ of seeds from the six lots were divided into four replications placed in identified and sealed individual aluminum packages (10 $\times$ $15 \mathrm{~cm})$, and submitted to a water bath at two temperatures $\left(40\right.$ and $45^{\circ} \mathrm{C}$ ) for four periods (8, 16,24 , and 48 hours), thus establishing eight combinations ( 2 temperatures $\times 4$ periods). Thus, a completely randomized design in an 8 $\times 6$ factorial scheme was obtained, with eight time/temperature combinations and six seed lots, with four replications.

The packages were removed from the water bath after the deterioration period and maintained at ambient temperature for 30 minutes to stabilize the seed temperature (Zucareli et al., 2011). Then, the degree of moisture and the physiological potential of the seeds from the six lots were determined by the first count and germination tests, according to the methodologies previously described. Subsequently, the percentage of dead seeds was determined at 7 days after sowing.

The Bartlettand Shapiro-Wilk tests were applied to verify the normality and homogeneity of variance of the data. Subsequently, the data were subjected to analysis of variance, and the means were compared by the Tukey test at $5 \%$ 
significance. The results of the first count and germination tests obtained for each treatment after the controlled deterioration, together with the data of initial characterization, were subjected to a simple linear correlation study at $5 \%$ significance.

\section{Results and Discussion}

The seed lots showed significant differences regarding the initial physiological potential of seeds, and most of the tests defined lot $A$ as the most vigorous and lot $F$ as the least vigorous. The other lots showed intermediate vigor (Table 1).

Table 1

Degree of moisture and initial physiological potential of six lots of sweet corn seeds.

\begin{tabular}{|ccccccccccc|}
\hline Lot & $\begin{array}{c}\mathrm{M} \\
(\%)\end{array}$ & $\begin{array}{c}\mathrm{G} \\
(\%)\end{array}$ & $\begin{array}{c}\mathrm{FC} \\
(\%)\end{array}$ & $\begin{array}{c}\mathrm{CT} \\
(\%)\end{array}$ & $\begin{array}{c}\mathrm{EC} \\
\left(\mu \mathrm{cm} \mathrm{cm}^{-1} \mathrm{~g}^{-1}\right)\end{array}$ & $\begin{array}{c}\text { AA } \\
(\%)\end{array}$ & $\begin{array}{c}\mathrm{SL} \\
(\mathrm{cm})\end{array}$ & $\begin{array}{c}\text { SDM } \\
(\mathrm{mg})\end{array}$ & $\begin{array}{c}\text { SE } \\
(\%)\end{array}$ & ERI \\
\hline $\mathrm{A}$ & 7.99 & $92 \mathrm{a}$ & $79 \mathrm{a}$ & 56 & 156 & $78 \mathrm{a}$ & $12.86 \mathrm{a}$ & $20.46 \mathrm{a}$ & $95 \mathrm{a}$ & 4.32 \\
\hline $\mathrm{B}$ & 8.04 & $89 \mathrm{ab}$ & $79 \mathrm{a}$ & 54 & 160 & $78 \mathrm{a}$ & $12.69 \mathrm{ab}$ & $19.83 \mathrm{a}$ & $91 \mathrm{ab}$ & 4.56 \\
\hline $\mathrm{C}$ & 8.32 & $89 \mathrm{ab}$ & $80 \mathrm{a}$ & 61 & 177 & $77 \mathrm{a}$ & $10.26 \mathrm{~cd}$ & $20.46 \mathrm{a}$ & $93 \mathrm{a}$ & 4.32 \\
\hline $\mathrm{D}$ & 8.18 & $94 \mathrm{a}$ & $84 \mathrm{a}$ & 51 & 190 & $52 \mathrm{~b}$ & $11.30 \mathrm{bc}$ & $19.82 \mathrm{a}$ & $90 \mathrm{ab}$ & 4.29 \\
\hline $\mathrm{E}$ & 8.02 & $92 \mathrm{a}$ & $82 \mathrm{a}$ & 53 & 161 & $60 \mathrm{~b}$ & $11.60 \mathrm{abc}$ & $14.19 \mathrm{~b}$ & $87 \mathrm{~b}$ & 3.89 \\
\hline F & 8.63 & $84 \mathrm{~b}$ & $58 \mathrm{~b}$ & 46 & 165 & $58 \mathrm{~b}$ & $9.68 \mathrm{~d}$ & $16.17 \mathrm{ab}$ & $86 \mathrm{~b}$ & 4.16 \\
\hline p-value & - & 0.00 & 0.00 & 0.13 & 0.49 & 0.00 & 0.00 & 0.00 & 0.00 & 0.17 \\
\hline CV (\%) & 3.60 & 3.19 & 4.62 & 13.3 & 16.1 & 8.72 & 5.86 & 12.6 & 2.94 & 7.73 \\
\hline
\end{tabular}

Means followed by the same letter in the columns do not differ from each other by the Tukey test at a $5 \%$ probability. Coefficient of variation (CV); degree of moisture (M); germination (G); first germination count (FC); cold test (CT); electrical conductivity (EC); accelerated aging (AA); seedling length (SL); seedling dry mass (SDM); seedling emergence in sand (SE); emergence rate index (ERI).

The segregation of lots in terms of vigor is necessary for the standardization of the controlled deterioration test, as the combination of time and temperature that provides a similar classification and a high correlation to the other standardized tests is sought. However, despite separated in terms of physiological potential, all lots initially presented a high percentage of germination, that is, above $70 \%$, a standard established for the crop (MAPA, 2013) and high vigor. According to Marcos (1999), these conditions are considered appropriate for studying the controlled deterioration test, as the use of lowquality lots with germination percentage below the standard established for commercialization is not suitable for this type of study.

The first germination count, determined four days after deterioration, showed high percentages of normal seedlings in all lots for the combination of $8 \mathrm{~h}-45^{\circ} \mathrm{C}$ (Table 2). However, the lowest values for this characteristic were found in the longest period of deterioration (48 hours of exposure), mainly at $45^{\circ} \mathrm{C}$. 
Table 2

First germination count of sweet corn seed lots with $20 \%$ water content after the controlled deterioration test with different combinations of time and temperature.

\begin{tabular}{ccccccccc} 
Lot & \multicolumn{7}{c}{ Time (hour) - Temperature $\left({ }^{\circ} \mathrm{C}\right)$} \\
\cline { 2 - 8 } & $8 \mathrm{~h}-40{ }^{\circ} \mathrm{C}$ & $16 \mathrm{~h}-40{ }^{\circ} \mathrm{C}$ & $24 \mathrm{~h}-40^{\circ} \mathrm{C}$ & $48 \mathrm{~h}-40^{\circ} \mathrm{C}$ & $8 \mathrm{~h}-45^{\circ} \mathrm{C}$ & $16 \mathrm{~h}-45^{\circ} \mathrm{C}$ & $24 \mathrm{~h}-45^{\circ} \mathrm{C}$ & $48 \mathrm{~h}-45^{\circ} \mathrm{C}$ \\
$\mathrm{A}$ & $52 \mathrm{aC}$ & $51 \mathrm{aC}$ & $83 \mathrm{aA}$ & $58 \mathrm{aC}$ & $83 \mathrm{abA}$ & $70 \mathrm{aB}$ & $54 \mathrm{abC}$ & $26 \mathrm{abD}$ \\
$\mathrm{B}$ & $59 \mathrm{aB}$ & $29 \mathrm{bD}$ & $55 \mathrm{bB}$ & $43 \mathrm{bC}$ & $86 \mathrm{aA}$ & $64 \mathrm{abB}$ & $62 \mathrm{aB}$ & $29 \mathrm{aD}$ \\
$\mathrm{C}$ & $55 \mathrm{aBC}$ & $26 \mathrm{bE}$ & $51 \mathrm{bcCD}$ & $44 \mathrm{bD}$ & $81 \mathrm{abcA}$ & $62 \mathrm{abB}$ & $45 \mathrm{bcD}$ & $23 \mathrm{abE}$ \\
$\mathrm{D}$ & $28 \mathrm{bD}$ & $22 \mathrm{bD}$ & $42 \mathrm{cdC}$ & $28 \mathrm{cD}$ & $79 \mathrm{abcA}$ & $61 \mathrm{abB}$ & $50 \mathrm{bC}$ & $30 \mathrm{aD}$ \\
$\mathrm{E}$ & $20 \mathrm{bDE}$ & $10 \mathrm{cE}$ & $31 \mathrm{eC}$ & $23 \mathrm{cdCD}$ & $74 \mathrm{bcA}$ & $56 \mathrm{bB}$ & $46 \mathrm{bcB}$ & $11 \mathrm{cE}$ \\
$\mathrm{F}$ & $20 \mathrm{bD}$ & $10 \mathrm{cD}$ & $34 \mathrm{deC}$ & $18 \mathrm{dD}$ & $73 \mathrm{cA}$ & $57 \mathrm{bB}$ & $37 \mathrm{cC}$ & $19 \mathrm{bcD}$
\end{tabular}

Means followed by the same uppercase letters in the row and lowercase letters in the column do not differ from each other by the Tukey test at a $5 \%$ probability.

The germination data obtained after deterioration (Table 3 ) revealed that the combination $8 \mathrm{~h}-45^{\circ} \mathrm{C}$ favored the percentage of normal seedlings for most lots, highlighting the lower performance of lots under the combination $48 \mathrm{~h}-45^{\circ} \mathrm{C}$.

\section{Table 3}

Germination of sweet corn seed lots with $20 \%$ water content after the controlled deterioration test with different combinations of time and temperature.

\begin{tabular}{ccccccccc} 
Lot & \multicolumn{7}{c}{ Time (hour) - Temperature $\left({ }^{\circ} \mathrm{C}\right)$} \\
\cline { 2 - 8 } & $8 \mathrm{~h}-40{ }^{\circ} \mathrm{C}$ & $16 \mathrm{~h}-40{ }^{\circ} \mathrm{C}$ & $24 \mathrm{~h}-40{ }^{\circ} \mathrm{C}$ & $48 \mathrm{~h}-40{ }^{\circ} \mathrm{C}$ & $8 \mathrm{~h}-45^{\circ} \mathrm{C}$ & $16 \mathrm{~h}-45^{\circ} \mathrm{C}$ & $24 \mathrm{~h}-45^{\circ} \mathrm{C}$ & $48 \mathrm{~h}-45^{\circ} \mathrm{C}$ \\
$\mathrm{A}$ & $81 \mathrm{abABC}$ & $77 \mathrm{aBC}$ & $90 \mathrm{aA}$ & $66 \mathrm{abD}$ & $85 \mathrm{abAB}$ & $80 \mathrm{aBC}$ & $73 \mathrm{aCD}$ & $40 \mathrm{aE}$ \\
$\mathrm{B}$ & $88 \mathrm{aA}$ & $72 \mathrm{aC}$ & $84 \mathrm{aAB}$ & $71 \mathrm{aC}$ & $88 \mathrm{aA}$ & $78 \mathrm{abBC}$ & $75 \mathrm{aC}$ & $39 \mathrm{aD}$ \\
$\mathrm{C}$ & $89 \mathrm{aA}$ & $73 \mathrm{aB}$ & $71 \mathrm{bB}$ & $66 \mathrm{abBC}$ & $83 \mathrm{abcA}$ & $74 \mathrm{abcB}$ & $60 \mathrm{bC}$ & $30 \mathrm{bcD}$ \\
$\mathrm{D}$ & $79 \mathrm{bcAB}$ & $61 \mathrm{bD}$ & $69 \mathrm{bcCD}$ & $64 \mathrm{abCD}$ & $83 \mathrm{abcA}$ & $79 \mathrm{aAB}$ & $71 \mathrm{aBC}$ & $38 \mathrm{abE}$ \\
$\mathrm{E}$ & $70 \mathrm{cAB}$ & $42 \mathrm{cD}$ & $66 \mathrm{bcBC}$ & $67 \mathrm{abBC}$ & $77 \mathrm{bcA}$ & $66 \mathrm{cBC}$ & $60 \mathrm{bC}$ & $23 \mathrm{cE}$ \\
$\mathrm{F}$ & $75 \mathrm{bcA}$ & $50 \mathrm{cE}$ & $62 \mathrm{cBC}$ & $59 \mathrm{bCD}$ & $75 \mathrm{cA}$ & $69 \mathrm{bcAB}$ & $50 \mathrm{cDE}$ & $31 \mathrm{abcF}$ \\
& & & $\mathrm{CV}(\%) 6.34$ & & &
\end{tabular}

Means followed by the same uppercase letters in the row and lowercase letters in the column do not differ from each other by the Tukey test at a $5 \%$ probability.

Theincrease in the deteriorationperiods at $45{ }^{\circ} \mathrm{C}$ showed a reduction in germination values. Rossetto, Lima and Guimarães (2004) worked with peanut seeds and found that the prolongation of the exposure period in the accelerated aging test caused more drastic effects on germination than the increase in temperature. A similar result was observed 
for watermelon seeds (Duarte, Borges, Costa, Silva, \& Santos, 2017), corroborating the results obtained in the present study.

On the other hand, Zucareli et al. (2011) observed that corn seeds had a higher variation in the results as the temperature increased. Bittencourt and Vieira (2006) worked with the accelerated aging in soybean seeds and also observed higher effects of temperature than the period of exposure to aging.

The higher sensitivity of sweet corn seeds due to the shape and thickness of the pericarp and chemical composition (Zucareli, Brzezinski, Guiscem, Henning, \& Nakagawa, 2014) makes them more susceptible to stress caused by the time of exposure and temperature, favoring their deterioration. It explains the difference in behavior between these seeds and those from large crops, such as corn and soybean, and the similarity with more sensitive seeds, such as those of vegetables.

Significant differences between sweet corn seed lots were observed in the first count and germination after deterioration for all evaluated combinations of time and temperature (Tables 2 and 3). However, not all of them similarly discriminated between lots.

The vast majority of the combinations between time and temperature for the first germination count after deterioration identified lot $A$ as the most vigorous and lots $E$ and $F$ as the least vigorous, except for the combinations $8 \mathrm{~h}-45^{\circ} \mathrm{C}, 24 \mathrm{~h}-45^{\circ} \mathrm{C}$, and $48 \mathrm{~h}-45^{\circ} \mathrm{C}$, which, differently from the others, defined lot $\mathrm{B}$ as that with the highest vigor (Table 2).

The results of germination after deterioration also indicated that the vast majority of tested combinations defined lots $A$ and $B$ as the most vigorous, except for some treatments that included other lots as the most vigorous (Table 3). Regarding the definition of less vigorous lots, the germination data after deterioration showed that all tested combinations classified lots $\mathrm{E}$ and $\mathrm{F}$ as those with less vigor, either together or separately, similarly to the first count.

In general, most of the evaluated combinations classified the best and worst physiological potential for lots $A$ and $F$, respectively, both in the first count and in the germination after deterioration, indicating coherence with the initial determinations. However, the treatments that provided segregation of lots similar to the initial classification, defined by the vigor tests already standardized, were $8 \mathrm{~h}-40^{\circ} \mathrm{C}, 8 \mathrm{~h}-45$ ${ }^{\circ} \mathrm{C}$, and $16 \mathrm{~h}-40^{\circ} \mathrm{C}$. The combination $16 \mathrm{~h}-40$ ${ }^{\circ} \mathrm{C}$ presented a high percentage of dead seeds, which compromises its use in the evaluation of the physiological potential of seeds.

Likewise, the combinations between the longest exposure period and the two tested temperatures $\left(48 \mathrm{~h}-40^{\circ} \mathrm{C}\right.$ and $\left.48 \mathrm{~h}-45^{\circ} \mathrm{C}\right)$ resulted in significantly lower percentages of germination than the other treatments. In this context, the combination between the highest temperature and the highest deterioration time $\left(48 \mathrm{~h}-45^{\circ} \mathrm{C}\right)$ stood out for providing a marked reduction in germination due to the death of most seeds, compromising and making the use of these combinations unfeasible to evaluate the vigor of seed lots by the controlled deterioration test.

Camara, Araújo, Ferreira, Alves and Moura (2008) stated that extreme temperatures cause internal changes in the seeds, which negatively affects the germination process, as it causes damage often irreversible. Zucareli et al. (2011) applied the controlled deterioration 
test in corn seeds with a water content of $20 \%$ and observed that the treatment with the highest temperature and deterioration time (48 $\mathrm{h}-48^{\circ} \mathrm{C}$ ) was very drastic, causing the death of seeds, similarly to the results obtained in this study.

According to Hampton and Tekrony (1995), seed aging occurs more quickly when they have high water content and are stored under high temperature, which explains the lower percentage of germination observed in the combination between longer time and higher temperature.

All tested combinations in the controlled deterioration test, evaluated through the germination and first germination count after deterioration, showed better performances for the most vigorous lots, especially lot $A$. These results corroborate with those found by Padilha, Vieira, Von Pinho and Carvalho (2001), who evaluated the behavior of corn seeds using the controlled deterioration test and reported that vigorous seeds have superior performance in a wider range of environmental conditions.

The first germination count after deterioration had positive and significant correlations between the initial emergence rate index and the combinations $8 \mathrm{~h}-40^{\circ} \mathrm{C}, 8$ $\mathrm{h}-45^{\circ} \mathrm{C}$, and $48 \mathrm{~h}-45^{\circ} \mathrm{C}$ at a $5 \%$ probability. In addition, most of the evaluated treatments at 4 days after deterioration (first germination count) presented significant correlations with seedling emergence in sand, except for the combinations $24 \mathrm{~h}-45^{\circ} \mathrm{C}$ and $48 \mathrm{~h}-45^{\circ} \mathrm{C}$. Positive and significant correlations were also observed between accelerated aging and the combinations $8 \mathrm{~h}-40^{\circ} \mathrm{C}$ and $48 \mathrm{~h}-40^{\circ} \mathrm{C}$ at a $5 \%$ probability. Seedling length and dry mass were significantly correlated with the combinations $24 \mathrm{~h}-45^{\circ} \mathrm{C}$ and $48 \mathrm{~h}-45^{\circ} \mathrm{C}$, respectively (Table 4). In general, the combinations $8 \mathrm{~h}-40^{\circ} \mathrm{C}$ and $8 \mathrm{~h}-45^{\circ} \mathrm{C}$ for the first germination count after deterioration showed the highest number of significant correlations with the vigor tests performed previously.

The germination after deterioration showed a significant and positive correlation at a $5 \%$ probability between the treatments 8 $\mathrm{h}-40^{\circ} \mathrm{C}, 8 \mathrm{~h}-45^{\circ} \mathrm{C}, 24 \mathrm{~h}-40^{\circ} \mathrm{C}, 24 \mathrm{~h}-45^{\circ} \mathrm{C}$, and $48 \mathrm{~h}-45^{\circ} \mathrm{C}$ and the emergence rate index. Also, the combinations $8 \mathrm{~h}-45^{\circ} \mathrm{C}$ and $16 \mathrm{~h}-40$ ${ }^{\circ} \mathrm{C}$ had a significant correlation coefficient with the seedling emergence test in sand (Table 5). Only the combinations $16 \mathrm{~h}-40^{\circ} \mathrm{C}$ and 48 $\mathrm{h}-40{ }^{\circ} \mathrm{C}$ presented a positive and significant correlation for seedling length. Moreover, the combinations correlated significantly with seedling dry mass were $8 \mathrm{~h}-40^{\circ} \mathrm{C}, 24 \mathrm{~h}-40$ ${ }^{\circ} \mathrm{C}, 24 \mathrm{~h}-45^{\circ} \mathrm{C}$, and $8 \mathrm{~h}-45^{\circ} \mathrm{C}$, the latter having the highest number of significant correlations with the vigor tests previously performed. 


\section{Table 4}

Simple linear correlation coefficients between the percentage of normal seedlings in the first germination count after controlled deterioration under different time/temperature combinations and other vigor tests using sweet corn seeds.

\begin{tabular}{ccccccccc|} 
Variable & \multicolumn{7}{c|}{ Time (hour) - Temperature $\left({ }^{\circ} \mathrm{C}\right)$} \\
\cline { 2 - 9 } & $8 \mathrm{~h}-40^{\circ} \mathrm{C}$ & $16 \mathrm{~h}-40^{\circ} \mathrm{C}$ & $24 \mathrm{~h}-40^{\circ} \mathrm{C}$ & $48 \mathrm{~h}-40^{\circ} \mathrm{C}$ & $8 \mathrm{~h}-45^{\circ} \mathrm{C}$ & $16 \mathrm{~h}-45^{\circ} \mathrm{C}$ & $24 \mathrm{~h}-45^{\circ} \mathrm{C}$ & $48 \mathrm{~h}-45^{\circ} \mathrm{C}$ \\
$\mathrm{FC}$ & 0.35 & 0.35 & 0.28 & 0.42 & 0.48 & 0.32 & 0.60 & 0.24 \\
$\mathrm{G}$ & 0.06 & 0.36 & 0.28 & 0.30 & 0.28 & 0.31 & 0.47 & 0.22 \\
$\mathrm{CT}$ & 0.75 & 0.53 & 0.52 & 0.74 & 0.60 & 0.50 & 0.36 & 0.16 \\
$\mathrm{EC}$ & -0.18 & -0.24 & -0.36 & -0.27 & -0.10 & -0.22 & -0.22 & 0.37 \\
$\mathrm{AA}$ & $0.92^{* *}$ & 0.70 & 0.74 & $0.86^{*}$ & 0.77 & 0.71 & 0.54 & 0.27 \\
$\mathrm{ERI}$ & $0.81^{*}$ & 0.58 & 0.53 & 0.61 & $0.87^{*}$ & 0.67 & 0.67 & $0.89^{*}$ \\
$\mathrm{SE}$ & $0.84^{*}$ & $0.93^{* *}$ & $0.90^{*}$ & $0.97^{* *}$ & $0.81^{*}$ & $0.92^{* *}$ & 0.56 & 0.59 \\
$\mathrm{SL}$ & 0.49 & 0.67 & 0.67 & 0.63 & 0.68 & 0.67 & $0.89^{*}$ & 0.35 \\
$\mathrm{SDM}$ & 0.81 & 0.76 & 0.69 & 0.77 & $0.84^{*}$ & 0.81 & 0.54 & $0.89^{*}$
\end{tabular}

*Significant at $5 \%$ probability. ${ }^{*}$ Significant at $1 \%$ probability. First germination count (FC); germination (G); cold test (CT); electrical conductivity (EC); accelerated aging (AA); emergence rate index (ERI); seedling emergence in sand (SE); seedling length (SL); seedling dry mass (SDM).

\section{Table 5}

Simple linear correlation coefficients between germination after controlled deterioration under different time/ temperature combinations and other vigor tests using sweet corn seeds.

\begin{tabular}{ccccccccc|} 
Variable & \multicolumn{7}{c|}{ Time (hour) - Temperature $\left({ }^{\circ} \mathrm{C}\right)$} \\
\cline { 2 - 9 } & $8 \mathrm{~h}-40^{\circ} \mathrm{C}$ & $16 \mathrm{~h}-40^{\circ} \mathrm{C}$ & $24 \mathrm{~h}-40^{\circ} \mathrm{C}$ & $48 \mathrm{~h}-40^{\circ} \mathrm{C}$ & $8 \mathrm{~h}-45^{\circ} \mathrm{C}$ & $16 \mathrm{~h}-45^{\circ} \mathrm{C}$ & $24 \mathrm{~h}-45^{\circ} \mathrm{C}$ & $48 \mathrm{~h}-45^{\circ} \mathrm{C}$ \\
$\mathrm{FC}$ & 0.24 & 0.38 & 0.58 & 0.70 & 0.31 & 0.72 & 0.40 & 0.13 \\
$\mathrm{G}$ & -0.07 & 0.32 & 0.41 & 0.67 & 0.15 & 0.45 & 0.41 & 0.20 \\
$\mathrm{CT}$ & 0.65 & 0.47 & 0.57 & 0.36 & 0.65 & 0.60 & 0.32 & 0.03 \\
$\mathrm{EC}$ & 0.14 & 0.44 & 0.01 & -0.01 & 0.00 & 0.28 & 0.22 & 0.07 \\
$\mathrm{AA}$ & 0.73 & 0.77 & 0.66 & 0.40 & 0.78 & 0.61 & 0.40 & 0.32 \\
$\mathrm{ERI}$ & $0.88^{*}$ & 0.64 & $0.85^{*}$ & 0.62 & $0.84^{*}$ & 0.40 & $0.81^{*}$ & $0.83^{*}$ \\
$\mathrm{SE}$ & 0.70 & $0.82^{*}$ & 0.80 & 0.66 & $0.93^{* *}$ & 0.46 & 0.78 & 0.60 \\
$\mathrm{SL}$ & 0.18 & $0.85^{*}$ & 0.70 & $0.88^{*}$ & 0.44 & 0.75 & 0.56 & 0.53 \\
$\mathrm{SDM}$ & $0.86^{*}$ & 0.65 & $0.84^{*}$ & 0.65 & $0.95^{* *}$ & 0.31 & $0.92^{*}$ & 0.80
\end{tabular}

*Significant at $5 \%$ probability. ${ }^{*}$ Significant at $1 \%$ probability. First germination count (FC); germination (G); cold test (CT); electrical conductivity (EC); accelerated aging (AA); emergence rate index (ERI); seedling emergence in sand (SE); seedling length (SL); seedling dry mass (SDM). 
According to Marcos, Pescarin, Komatsu, Demétrio and Fancelli (1984), a significant correlation indicates a similar trend of variation between two variables, but it does not mean that the lot quality is estimated similarly by the two characteristics. Thus, the definition of the best treatment to evaluate the controlled deterioration test on sweet corn seeds requires the evaluation of the first count and germination after deterioration together with the correlations they showed with the other vigor tests already standardized. In this sense, the combinations $8 \mathrm{~h}-40^{\circ} \mathrm{C}$ and $8 \mathrm{~h}$ - $45^{\circ} \mathrm{C}$ presented a behavior similar to those initially determined and correlated positively and significantly with the rate and percentage of seedling emergence in sand for the two variables evaluated after deterioration.

The most efficient combination of time and temperature for the evaluation of the controlled deterioration test, as well as any other evaluation, varies between different species (Zucareli et al., 2011), as the structure and chemical and genetic composition of seeds directly influence their physiological responses. Alves, Godoy, Candidoand Sá(2011) evaluated the physiological potential of arugula seeds through the controlled deterioration test and concluded that this test was not sensitive enough to assess the physiological quality of seeds of the tested cultivars. On the other hand, Dutra and Medeiros (2008) worked with cotton and observed that the combination of $24 \%$ water content for 48 hours at $40^{\circ} \mathrm{C}$ in the controlled deterioration test was efficient to detect differences in vigor between the seed lots.

Zucareli et al. (2011) studied the efficiency of the controlled deterioration test to evaluate the physiological potential of common corn seeds and found that the combinations $24 \mathrm{~h}-45^{\circ} \mathrm{C}, 48 \mathrm{~h}-45^{\circ} \mathrm{C}$, and 16 $\mathrm{h}-45^{\circ} \mathrm{C}$ for seeds with water content adjusted to 15,20 , and $25 \%$, respectively, were efficient in assessing vigor, unlike the results obtained in the present study. It is mainly due to differences in chemical and genetic constitution between common and sweet corn seeds (Kwiatkowski \& Clemente, 2007), which are mainly reflected in their physical conformation and physiological responses.

The combination $24 \mathrm{~h}-45^{\circ} \mathrm{C}$ has been one of the most used in the controlled deterioration test, mainly for vegetable species such as cabbage (Bernardes et al., 2015), okra (Torres et al., 2013), and coriander (Torres et al., 2012). For sweet corn, this combination was not correlated with other vigor tests previously performed. It may be related to the higher sensitivity of these seeds to deterioration, that is, 24 hours of exposure can be considered very drastic for this species, with 8 hours being the most suitable period.

The combinations $8 \mathrm{~h}-40{ }^{\circ} \mathrm{C}$ and $8 \mathrm{~h}$ $-45^{\circ} \mathrm{C}$ were the most efficient to evaluate the vigor of sweet corn seeds using the controlled deterioration test. These combinations presented the best results and reduced the time necessary to perform the test, as they were performed at the shortest exposure periods, which is essential for a vigor test. Also, the evaluation of the first germination count, carried out four days after the deterioration, was more efficient relative to time than germination because it streamlines the decisions that must be taken regarding the management of seeds during the stages of production. 


\section{Conclusion}

The controlled deterioration test, evaluated by the germination and first germination count, is adequate to estimate the physiological potential of sweet corn seeds.

The combinations $8 \mathrm{~h}-40^{\circ} \mathrm{C}$ and $8 \mathrm{~h}$ $-45^{\circ} \mathrm{C}$ for seeds with water content adjusted to $20 \%$ are efficient in distinguishing the vigor of sweet corn seed lots for first count and germination evaluated after deterioration.

The shorter exposure period (8 hours) and first germination count after deterioration are more suitable for evaluating the vigor of sweet corn seeds using the controlled deterioration test, as they reduce the time to perform the test.

\section{Acknowledgments}

This study was supported by the Coordination for the Improvement of Higher Education Personnel, Brazil (CAPES).

\section{References}

Alves, C. Z., Godoy, A. R., Candido, A. C. S., \& Sá, M. E. (2011). Qualidade fisiológica de sementes de Eruca sativa L. pelo teste de deterioração controlada. Ciência Rural, 41(12), 2090-2095. doi: 10.1590/ S010384782011001200009

Association of Official Seed Analysts (2009). Seed vigor testing handbook. Lincoln: AOSA.

Barbieri, A. P. P., Menezes, N. L., Conceição, G. M., \& Tunes, L. M. (2012). Teste de lixiviação de potássio para a avaliação do vigor de sementes de arroz. Revista Brasileira de
Sementes, 34(1), 117-124. doi: 10. 1590/ S0101-31222012000100015

Bento, S. R. S. O., Santos, A. E. O., Melo, D. R. M., \& Torres, S. B. (2010). Eficiência dos testes de vigor na avaliação da qualidade fisiológica de sementes de mulungu (Erythrina velutina WILLD). Revista Brasileira de Sementes, 32(4), 111-117. doi: 10.1590/ S0101-31222010000400012

Bernardes, P. M., Lopes, J. C., Zanotti, R. F., Motta, L. B., Mengarda, L. H. G., \& Spadeto, C. (2015). Testes de deterioração controlada e de envelhecimento acelerado na avaliação da qualidade fisiológica de sementes de repolho. Nucleus, 12(1), 5158. doi: 10.3738/1982.2278.1225

Bittencourt, S. R. M., \& Vieira, R. D. (2006). Temperatura e período de exposição de sementes de milho no teste de envelhecimento acelerado. Revista BrasileiradeSementes, 28(3), 161-168. doi: 10.1590/S0101-31222006000300023

Camara, C. A., Araújo, J. C., Neto, Ferreira, V. M., Alves, E. U., \& Moura, F. B. P. (2008). Caracterização morfométrica de frutos e sementes e efeito da temperatura na germinação de Parkia pendula (Willd.) Benth. Ex Walp. Ciência Florestal, 18(3), 281-290. doi: 10.5902/19805098439

Cícero, S. M., \& Vieira, R. D. (1994). Teste de frio. In R. D. Vieira, \& N. M. Carvalho (Eds.), Testes de vigor em sementes (p. 151-164). Jaboticabal: FUNEP/UNESP.

Duarte, R. R., Borges, R. S., Costa, G. G. S., Silva, E. M., \& Santos, J. M. (2017). Envelhecimento acelerado tradicional e alternativo em sementes de melancia. Revista de Agricultura Neotropical, 4(1), 119-123. doi: 10.32404/rean.v4i5.2207 
Dutra, A. S., \& Medeiros, S, Fo. (2008). Teste de deterioração controlada na determinação do vigor em sementes de algodão. Revista Brasileira de Sementes, 30(1), 19-23. doi: 10.1590/S0101-31222008000 100003

Hampton, J. G., \& Tekrony, D. M. (1995). Controlled deterioration test. In J. G. Hampton, \& D. M. Tekrony, Handbook of vigour test methods (pp. 70-78). Zurich: International Seed Testing Association.

Kwiatkowski, A., \& Clemente, E. (2007). Características do milho doce (Zea mays) para industrialização. Revista Brasileira de Tecnologia Agroindustrial, 1(2), 93-103. doi: 10.3895/S1981-3686200700020001 0

Maguire, J. D. (1962). Speed of germination-aid in selection and evaluation for seedling emergence and vigor. Crop Science, 2(2), 176-177. doi: 10.2135/cropsci1962.0011 183X000200020033x

Marcos, J., Fo. (1999). Teste de envelhecimento acelerado. In F. C. Krzyzanowski, R. D. Vieira, \& J. B. França Neto (Eds.), Vigor de sementes: conceitos e testes (cap. 3, p. 1-24). Londrina: ABRATES.

Marcos, J., Fo. (2015). Fisiologia de sementes de plantas cultivadas ( $2 a$ ed.). Londrina: ABRATES.

Marcos, J., Fo, Pescarin, H. M. C., Komatsu, Y. H., Demétrio, C. G. B., \& Fancelli, A. L. (1984). Testes para avaliação do vigor de sementes de soja e suas relações com emergência de plântulas no campo. Pesquisa Agropecuária Brasileira, 19(5), 605-613. Recuperado de http://seer. sct.embrapa.br/index.php/pab/article/ view/15720
Marinho,J.L.,Fonseca,I.C.B.,\&Zucareli,C.(2020). Hydration methods and physiological potential of sweet corn seeds. Bioscience Journal, 36(4), 1283-1291. doi: 10.14393/ BJ-v36n4a2020-47813

Ministério da Agricultura, Pecuária e Abastecimento (2009). Regras para análise de sementes. Brasília: MAPA/ACS. Recuperado de http://www.agricultura. gov.br/assuntos/laboratorios/arquivospublicacoes laboratorio/regras-paraanalise-de-sementes. pdf/view

Ministério da Agricultura, Pecuária e Abastecimento (2013). Instrução Normativa $n^{\circ} 45$ de 2013. Secretaria de Defesa Agropecuária. Brasília: MAPA/DAS/ CSM. Recuperado de http://www. abrasem. com.br/wp-content/uploads/2012/10/ Instru\%C3\%A7\%C3\%A3o-Normativan\%C2\%BA-45-de-17-de-Setembro-de2013-Padr\%C3\%B5es-de-Identidadee-Quali idade-Prod-e-Comercde-Sementes-Grandes-CulturasRepublica\%C3\%A7\%C3\%A3o-DOU-20. 09.13. pdf

Morais, C. S. B., \& Rossetto, C. A. V. (2013). Testes de deterioração controlada e envelhecimento acelerado para avaliação do vigor em nabo forrageiro. Revista Ciência Agronômica, 44(4), 703-713. doi: 10.1590/ S1806-66902013000400006

Nakagawa, J. (1999). Testes de vigor baseados no desempenho de plântulas. In F. C. Krzyzanowski, R. D. Vieira, \& J. B. França Neto (Eds.), Vigor de sementes: conceitos e testes (cap. 2, p. 1-24). Londrina: ABRATES.

Padilha, L., Vieira, M. G. G. C., Von Pinho, E. V. R., \& Carvalho, M. L. M. (2001). Relação 
entre o teste de deterioração controlada e o desempenho de sementes de milho em diferentes condições de estresse. Revista Brasileira de Sementes, 23(1), 198-204. doi: 10.17801/0101-3122/rbs. v23n1p198-204

Parera, C. A., Cantlife, D. J., Stofella, P. J., \& Scully, B. T. (1995). Field emergence of shrunken-2 corn predicted by single-and multiple-vigor laboratory tests. Journal of the American Society of Horticultural Science, 120(1), 128-132. doi: 10.21273/ JASHS.120.1.128

Rossetto, C. A. V., Lima, T. M., \& Guimarães, E. C. (2004). Envelhecimento acelerado e deterioração controlada em sementes de amendoim. Pesquisa Agropecuária Brasileira, 39(8), 795-801. doi: 10.1590/ S0100-204X2004000800010

Santos, F., Trani, P. E., Medina, P. F., \& Parisi, J. J. D. (2011). Teste de envelhecimento acelerado para avaliação da qualidade de sementes de alface e almeirão. Revista Brasileira de Sementes, 33(2), 322-330. doi: 10.1590/S0101-31222011000200015

Silva, J. B., \& Vieira, R. D. (2010). Deterioração controlada em sementes de beterraba. Revista Brasileira de Sementes, 32(1), 6976. doi: 10.1590/S0101-3122201000010 0008
Torres, S. B., Dantas, A. H., Pereira, M. F. S., Benedito, C. P., \& Silva, F. H. A. (2012). Deterioração controlada em sementes de coentro. Revista Brasileira de Sementes, 34(2), 319-326. doi: 10.1590/S0101-3122 2012000200018

Torres, S. B., Gomes, M. D. A., Silva, F. G., Benedito, C. P., \& Pereira, F. E. C. B. (2013). Controlled deterioration to evaluate okra seed vigor. Horticultura Brasileira, 31(2), 317-321. doi: 10.1590/S0102-05362013000200023

Zucareli, C., Brzezinski, C. R., Guiscem, J. M., Henning, F. A., \& Nakagawa, J. (2014). Qualidade fisiológica de sementes de milho doce classificadas pela espessura e largura. Pesquisa Agropecuária Tropical, 44(1), 71-78. doi: 10.1590/S1983-406320 14000100009

Zucareli, C., Cavariani, C., Sbrussi, C. A. G., \& Nakagawa, J. (2011). Teste de deterioração controlada na avaliação do vigor de sementes de milho. Revista Brasileira de Sementes, 33(4), 732-742. doi: 10.1590/ S0101-31222011000400015 
